REVISTA de
PEDAGOGIE

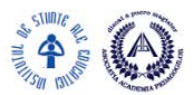

JOURNAL of PEDAGOGY

http://revped.ise.ro

Print ISSN 0034-8678; Online ISSN: 2559 - 639X

\title{
DO AQUATIC ACTIVITIES BOOST SOCIAL SKILLS FOR CHILDREN WITH AUTISM SPECTRUM DISORDERS?
}

\author{
DEZVOLTĂ ACTIVITĂȚILE ACVATICE COMPETENȚELE SOCIALE ALE \\ COPIILOR CU TULBURĂRI DIN SPECTRUL AUTIST?
}

\section{Maria BELLA}

$$
\text { Journal of Pedagogy, } 2019 \text { (2), } 151 \text { - } 171
$$

https://doi.org/10.26755/RevPed/2019.2/151

The online version of this article can be found at: http://revped.ise.ro/category/2019-en/

\section{(9)(1)(2)}

This work is licensed under the Creative Commons Attribution-NonCommercial-ShareAlike 4.0 International License. To view a copy of this license, visit http://creativecommons.org/licenses/by-nc-sa/4.0/ or send a letter to Creative Commons, PO Box 1866, Mountain View, CA 94042, USA.

Published by:

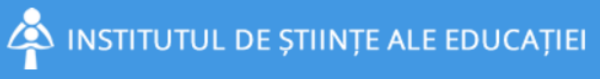

http://www.ise.ro/

Further information about Revista de Pedagogie - Journal of Pedagogy can be found at:

Editorial Policy: http://revped.ise.ro/editorial-policy/

Author Guidelines: http://revped.ise.ro/the-writer-guide-2/ 


\title{
DO AQUATIC ACTIVITIES BOOST SOCIAL SKILLS FOR CHILDREN WITH AUTISM SPECTRUM DISORDERS?
}

\author{
Aristotle University of Thessaloniki, \\ Thessaloniki, Greece \\ bella-maria81@windowslive.com
}

Maria Bella*

\begin{abstract}
This paper provides a number of aquatic programmes, and critically analyzes methods and techniques used to develop social skills in young children with Autism Spectrum Disorders (ASD). Social skills are interpreted through a ToM theory lens, emphasizing interactions, such as understanding, explaining, predicting, and manipulating the behavior of themselves and others. Based on these elements, the purpose of this review is to study the role of adapted group aquatic programmes and its effect on children with ASD to understand the concept of peers and learning the benefits of two important social skills, teamwork, and relationships. An online search through ProQuest and First Search resulted in seven studies of diverse methodologies. All these studies support the value of these programmes as a means of social skills' development. Qualitative as well as quantitative data which included, checklists, interviews, and tests, indicated these programmes benefit ASD children's' social skills, such as cooperation, communication and increase in self-esteem. Findings suggested that children with ASD have opportunities to make new friends, feel more comfortable in a group and reduce anxiety through swimming. These relationships can continue, as they discover other common interests. More longitudinal studies are needed to develop aquatic activities as an extracurricular activity and the planning process to achieve the intended outcomes. By synchronizing theory with sports activities and teamwork, children with ASD can feel a deep sense of accomplishment upon achievement.
\end{abstract}

Keywords: autism spectrum disorders, interactions, social skills, swimming, teamwork.

* PhD. Graduate, Alumni Aristotle University of Thessaloniki, Thessaloniki, Greece. 


\section{Rezumat}

Articolul trece în revistă o serie de programe acvatice şi analizează metode şi tehnici pentru dezvoltarea abilită ilor sociale la copiii mici cu tulburări ale spectrului de autism (ASD). Abilită ile sociale sunt interpretate prin intermediul teoriei min ii (ToM), punând accent pe interac iuni de tipul în elegerii explica iilor, a predic iilor şi a gestionării comportamentului propriu şi al celorlal $i$. Pe baza acestor elemente, scopul prezentării de fa ă este de a studia rolul programelor acvatice de grup adaptate şi efectul acestora asupra copiilor cu autism pentru a în elege conceptul de „colegi” "si pentru a învă a beneficiile a două abilită i sociale importante, respectiv munca în echipă şi rela ionarea. O căutare online prin ProQuest şi First Search s-a finalizat cu şapte studii cu metodologii de cercetare diverse. Toate aceste studii sus in valoarea programelor acvatice ca mijloace de dezvoltare a abilită ilor sociale. Datele calitative, precum şi cele cantitative care au inclus liste de verificare, interviuri şi teste, au indicat că aceste programe dezvoltă abilită ile sociale ale copiilor cu autism, cum ar fi cooperarea, comunicarea şi creşterea stimei de sine. Rezultatele au sugerat că prin aceste programe copiii cu autism au avut oportunită i de a-şi face prieteni noi, de a se sim i mai confortabil într-un grup şi de a îşi reduce anxietatea prin înot. Aceste rela ii pot continua, pe măsură ce descoperă alte interese comune. Sunt necesare mai multe studii longitudinale pentru a dezvolta activită ile acvatice ca activită i extracurriculare printr-o proiectare adecvată pentru a atinge rezultatele inten ionate. Prin sincronizarea teoriei cu activită ile sportive şi munca în echipă, copiii cu autism au experien a unui profund sentiment de realizare personală.

Cuvinte cheie: abilită i sociale, interac iuni, înot, muncă în echipă, tulburări ale spectrului autist.

\section{Introduction}

The phrase "exercise is socialization" is a common refrain among adapted physical educators and health practitioners. A wealth of sport and psychological research gives credibility to this truism by evaluating different sports training programmes which develop and improve social skills, such as cooperation, communication, and social awareness in young children with ASD (Horvat et al., 2019). On this basis, swimming is a good allround activity which has a myriad of extraordinary benefits for the body and mind that can boost the quality of life and socialization for children with ASD. The vast majority of the studies are primarily based on experts' and/or parents' views, beliefs, perceptions or observations about the effect 
of aquatic activities and the way children with ASD reduce the risk of accidental drowning-and bring more confidence, and coordination into their lives (Buchanan, Miedema \& Frey, 2017; Sato et al., 2015).

Most of the aquatic objectives for children with ASD according to Kraft and Leblanc (2018) focus on combining water and play activities as a dynamic set that causes social interactions since it is a great way for them to meet new friends in a fun environment within no-pressure situations. This condition also can help them "break the ice" and avoid awkward silences that can happen when they are meeting one or more other children. Aleksandrović et al. (2015) also highlight the important role of aquatic group activities in changing behaviours, building confidence, connecting with others, and having a sense of purpose, as well as in developing social initiative. Different studies have also stressed the physical educator's role on the beneficial impact of aquatic activities and sharing their aspirations and strategies supporting a healthy body and social development in young children with ASD (e.g., Winnick \& Porretta, 2016).

Given these facts, the author's aim is to further investigate the impact of aquatic programmes on promoting the development of social skills in children with ASD within an inclusive and fun environment by making use of literature review.

\subsection{Theoretical Perspective}

In recent years, research in physical education has increasingly been developed by the work of a range of prominent theorists in social theory (e.g., Foucault, Giddens, Bernstein, and Bourdieu). According to Bourdieu (1990), day-to-day activities are produced by an interaction of individuals in a social environment, and it is through participation in social practices that the logic of the field is embodied and reproduced. Today, Bourdieu's concept is characterized as a helpful measure which can determine individuals' motility in the physical activity and improvement of their social skills.

On the other hand, children with ASD present a multifaceted social deficit 
and limitations to interact with other children or/and not participate easily in the physical activity. According to Premack and Woodruff (1978) and the Theory of Mind (ToM), social behaviors are not impaired; some abilities are preserved, especially in high-functioning autistic (HFA) individuals. One explanation of the mix of core challenges and preserved abilities could be explained by a single deficit - an inability to attribute mental states to oneself and others. Andrés-Roqueta et al. (2016) argue that in the case of children with ASD, the Theory of Mind (ToM) and the skills that derive from it can be acquired through a cooperative learning process, such as play. More specifically, Lee and Porretta (2013) asserted that water is an essential part of the daily life and therefore, plays an important role in a child's development. On this basis, aquatic programmes are an optimal form of physical activity which may affect their ability to remain focused on a task at hand. Several studies support the idea that aquatic activities or programmes incorporate a number of promising strategies for social skills training such as providing a fun environment, and natural reinforcement (Dartt, 2015; Jull \& Mirenda, 2016; Pan, 2010).

\subsection{Benefits of aquatic activities}

Based on contemporary literature, aquatic programmes are usually supervised by a multidisciplinary team involving adapted physical educators or instructors and psychologists. According to Lepore et al. (2015), a successful aquatic programme includes: (1) a structured teaching model; (2) supplementing with adult teaching and peer mediation to increase initiation; and (3) the use of adapted environments established for water play activities to increase spontaneous communication. Furthermore, aquatic activity is an important part of a healthy social lifestyle, it is fun and has a great potential to be a lifetime activity. For this reason, according to Kanupka et al. (2016), children with ASD should be introduced to it early in aquatic classes.

A carefully designed group aquatic programme that includes a pre- and post-assessment and an ongoing review of instruction can improve social skills, such as cooperation and communication. Because those children with ASD find many experiences easier in the pool, participation in aquatic 
programmes feels more comfortable, improves their ability to play cooperatively and boosts their overall health and well-being. In general, aquatic activities are not always easily adaptable to those with multiple mental or neurodevelopmental disorders, and physical educators often need more information on how to include such children.

Based on these assumptions and theoretical perspective, these recommendations are critical to aquatic programmes research because small, but consequential adaptations in a study's design for children with ASD, or on the way a study is reported, can affect how physical educators view a study in particular, and aquatic programmes in general.

\section{Method}

The current review was conducted to locate, evaluate and synthesize all the empirical evidence which addresses three primary areas: (1) what does research on aquatic activities or programmes tell about their impact on social skills development for children with ASD? (2) Are there any robust results that can help and train physical educators or instructors to select the right activities for children with ASD on the basis of: a) its suitability for adaptation, b) the degree of difficulty, and c) both direct and indirect thirdparty involvement? (3) Are there particular points that need to be borne in mind for future research, through the same body of research? As suggested by Templier and Paré (2015), there are just six steps to conduct a review, which were followed by the researcher in this study (Table no. 1)

Table no. 1. Six steps of the review

\begin{tabular}{|c|c|c|}
\hline First part & Second part & Third part \\
\hline $\begin{array}{l}\text { 1. Formulating the research } \\
\text { question(s) \& objective(s) } \\
\text { 2. Searching the literature }\end{array}$ & $\begin{array}{l}\text { 3. Evaluating the applicability of } \\
\text { the material } \\
\text { 4. Assessing the quality of } \\
\text { primary studies }\end{array}$ & $\begin{array}{ll}\text { 5. } & \text { Extracting data } \\
\text { 6. } & \text { Analyzing data }\end{array}$ \\
\hline
\end{tabular}

The first step which conducted the review has been presented above and was used to identify studies for possible inclusion in this review. The 
remaining five steps were conducted in a manner that becomes clear in the remaining part of the article. In the next step, searches were conducted in multiple electronic databases via Education Resources Information Center (ERIC), via EBSCOhost, Scopus, Wiley Online Library WorldCat, and in Semantic Scholar. A specific set of words were selected as the ones that had the most results: (swim OR aquatic activities *autism OR aquatic techniques *ASD OR water play activities *autism) AND (social skills OR social interactions OR social development OR social evaluation*) AND (autistic childhood OR adolescence). In this review, the researcher selected particular terms to refer to very distinct concepts, some of them using the same terms to denote different conceptual constructs.

Table no. 2. List of search terms

\begin{tabular}{|c|c|c|c|c|}
\hline Electronic databases & $\begin{array}{c}\text { Aquatic } \\
\text { activities terms }\end{array}$ & $\begin{array}{l}\text { Social skills } \\
\text { terms }\end{array}$ & $\begin{array}{c}\text { Participants } \\
\text { parameters } \\
\text { terms }\end{array}$ & $\begin{array}{l}\text { Excluding } \\
\text { terms }\end{array}$ \\
\hline $\begin{array}{l}\text { ERIC } \\
\text { EBSCOhost } \\
\text { Scopus } \\
\text { Wiley Online Library } \\
\text { WorldCat }\end{array}$ & $\begin{array}{l}\text { Aquatic } \\
\text { exercise } \\
\text { Swim } \\
\text { Water exercise } \\
\text { Water fun play } \\
\text { Swim sports } \\
\text { play } \\
\text { Pool play } \\
\text { Recreational } \\
\text { aquatic }\end{array}$ & $\begin{array}{l}\text { Social } \\
\text { interaction } \\
\text { Communication } \\
\text { Social ability } \\
\text { Social } \\
\text { relationships } \\
\text { Cooperation } \\
\text { Understanding } \\
\text { Initiative }\end{array}$ & $\begin{array}{l}\text { Asperger } \\
\text { High } \\
\text { Functioning } \\
\text { Autism } \\
\text { High } \\
\text { cognitive } \\
\text { level (IQ) } \\
\text { Borderline } \\
\text { level } \\
\text { Age: 5-17 } \\
\text { years-old }\end{array}$ & $\begin{array}{l}\text { Abnormal\$ } \\
\text { Aphas\$ } \\
\text { Disab\$ } \\
\text { Disord\$ } \\
\text { Hyperact\$ } \\
\text { Impair\$ } \\
\text { Retard\$ }\end{array}$ \\
\hline
\end{tabular}

Note. $\$$ is a database search convention that indicates a search for the preceding word stem with all possible endings

All searches were done by the author, thus resulting 139 studies, which were limited to 75 after scanning through the titles and subtitles, for possible inclusion. In the next step, abstracts of these studies were reviewed to identify studies meeting the inclusion criteria (see Table no. 2). In the third step, reference lists of studies meeting these criteria were then reviewed to identify additional articles for possible inclusion. In the fourth step, the applicability of the material was evaluated and the quality of studies was assessed (e.g., participants, measures, outcomes). Many studies were excluded mainly because they came from other disciplines, such as medicine. This analysis 
is investigating only the educational process and how children with ASD can manage social behavior in aquatic activities in a pool environment and interact through time with children. As shown in Table no. 3, in order to be included in this review, studies had to contain participants with an ASD diagnosis (i.e., autism, Asperger's, or PDD-NOS). Aquatic activities were defined as fun and play actions requiring physical exertion.

Table no. 3. Inclusion and exclusion criteria

\begin{tabular}{|l|l|l|}
\hline \multicolumn{1}{|c|}{ Criteria } & \multicolumn{1}{|c|}{ Inclusion } & \multicolumn{1}{c|}{ Exclusion } \\
\hline $\begin{array}{l}\text { Publication } \\
\text { date }\end{array}$ & $\begin{array}{l}\text { September 2010 to May 2019 } \\
\text { (e.g., research journals and thesis) }\end{array}$ & $\begin{array}{l}\text { Published pre 2010 } \\
\text { (e.g., discussion editorial, } \\
\text { abstracts unofficial data) }\end{array}$ \\
\hline Language(s) & English language & Other languages \\
\hline $\begin{array}{l}\text { Research } \\
\text { population }\end{array}$ & $\begin{array}{l}\text { Children and adolescents 5 to 17- } \\
\text { year-old of both genders with ASD } \\
\text { (high or borderline IQ) }\end{array}$ & $\begin{array}{l}\text { Children, adolescents or } \\
\text { adults with moderate and } \\
\text { severe IQ or/and any other } \\
\text { disorders or disabilities }\end{array}$ \\
\hline $\begin{array}{l}\text { Intervention } \\
\text { type }\end{array}$ & $\begin{array}{l}\text { Original studies with mixed research } \\
\text { methods (i.e., interviews, } \\
\text { observations, test, etc.) }\end{array}$ & $\begin{array}{l}\text { Meta-analysis, longitudinal } \\
\text { or Cross-sectional studies, } \\
\text { single case study or } \\
\text { reviews }\end{array}$ \\
\hline Results & $\begin{array}{l}\text { Aquatic activities or programmes } \\
\text { only as an educational method for } \\
\text { children with ASD and social skills } \\
\text { development }\end{array}$ & $\begin{array}{l}\text { Studies with no specific or } \\
\text { clearly social outcomes or } \\
\text { studies which focus on } \\
\text { aquatic activities as } \\
\text { therapy process }\end{array}$ \\
\hline
\end{tabular}

\subsection{Search procedure}

The list of studies as mentioned was collected from electronic databases. A final set of seven papers were included in the review for analysis (Figure no. 1). All of the studies in this review employed an intervention that met the construct definitions of aquatic fun play and activities interventions. 


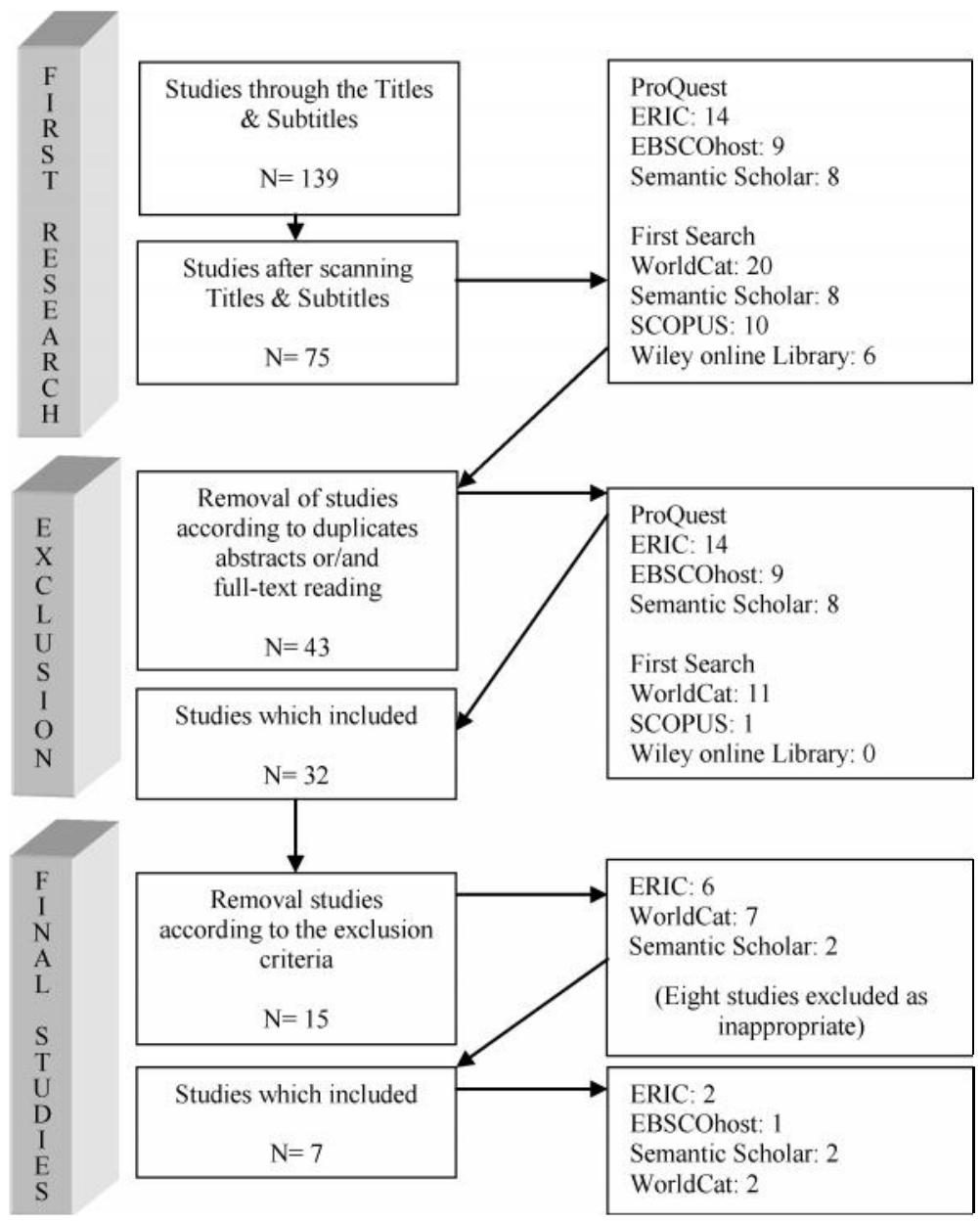

Figure no. 1. Search procedure

\subsection{Data extraction}

Each study was assessed for inclusion, and exclusion criteria and included studies that summarized the features, such as (a) participant characteristics, (b) social behavior taught, (c) teaching procedures, (d) outcomes, and (e) methodology. The effects of aquatic activities and the changes in the 
frequency of social behavior and interactions were summarized through reporting the statistical findings of designs. Furthermore, there was a wide set of methods and measures used for evaluating participants with ASD and activities or programmes, but the wide range of methodologies made the comparison among all the studies difficult, and in some cases impossible.

\section{Results}

\subsection{Participants}

Collectively, the 7 studies provided intervention to a total of 72 children and adolescents with ASD. Forty-one (56.9\%) of the participants were male and four $(5.5 \%)$ were female, consistent with the male to female ratio within the ASD population (American Psychiatric Association, 2013). The gender of the remaining 28 participants' (38\%) was not identified. The mean age was 12.5 years old (range, 5-17). High Functioning Autism (HFA) and Asperger Syndrome were the most common diagnoses $(n=30)$ followed by Pervasive developmental disorder otherwise not specified (PDD-NOS) $(\mathrm{N}=24)$ and invasive developmental disorder with features of autism spectrum $(\mathrm{N}=18)$. Furthermore, the largest number of participants had a high cognitive level or relevant disabilities $(\mathrm{N}=42)$ who were included in primary and secondary schools.

\subsection{Settings}

In most studies, aquatic activities occurred in one setting and the effects on dependent variables were assessed in the same setting (Battaglia et al., 2019; Pan, 2010; Pimenta et al., 2016; Tucker, 2016). The researcher has employed a large vocabulary of terms to refer to the same, similar, or related constructs like the one defined here as aquatic activities. In this review, most of the studies were designed to investigate the effects of aquatic activities as an educational method for specific social skills development for individuals with ASD. All studies were conducted in private pool centres. 


\subsection{Aquatic exercises training protocols}

The majority of studies $(\mathrm{N}=4)$ included 10 to 15 weeks adapted aquatic sessions which were divided into categories, such as social and floor warmup activities, one-to-two small group instruction, whole group games/ activities, and cool-down activities (Fragala-Pinkham et al., 2011). In only one of the rests of the studies, participants engaged in three different aquatic skills, essential for movement exploration in water and swimming, in a one-to-one training format (Yanardag, 2015). Finally, three studies used a structured intervention programme, such as SPARK programme, which consisted of 36 sessions (Najafabadi et al., 2018), a twenty-one weeks water exercise swimming program (WESP) (Pan, 2010) and a twelve weeks multisystemic aquatic programme (CI-MAT) as a form of therapy (Battaglia, 2019).

\subsubsection{Exercises for social skills}

All programmes which were presented in this review provide games and group activities that are specific to the principles of research goals. Participants work to gain independence in water, they are also able to become active members of the group while maintaining the one-to-two instructional setting. Through aquatic activities, participants were able to take advantage of social interaction with other members of groups and yet still benefit from the constant attention of their physical educator.

\subsection{Procedures}

The procedures used to teach social skills were reported in 6 of the 7 studies (90\%). Groups with fun aquatic activities and/or exercises were used in $80 \%$ percent of the studies in this review. It is clear that this technique promotes effective interpersonal relations and social transactions among participants. As shown in the study by Pan (2015), water exercise swimming programme allowed participants to explore properties of water by interacting with other participants in a managed way to develop experience in a supported environment. 
According to Tucker's observations (2016), children or/and adolescents with ASD who participated in aquatic actions had the possibility for significant learning, allowing the experience to encourage, to develop and start with a deep understanding of the situation from the 'opposite' point of view. Some activities which were used to measure social and emotional integration and interdependence by Battaglia (2019) showed that aquatic techniques have benefits for participants with ASD because it reflects the real-life as a model to their playing. In this research, the effect of aquatic activities agrees with one more study which had the same target.

In the research by Primenta et al. (2016), aquatic activity intervention is based on the parameters of aquatic skills development for individuals with disabilities as proposed by Lepore, Gayle, Stevens (1998) and Winnick (2004) which emphasizes orientation in the water, as well as both physical and social development. The findings showed an important rate of development of social communication and interaction skills. Based on these findings, the general conclusion is that this technique has a positive effect on teaching social skills for participants with ASD.

Although in a few studies, such as the one of Fragala-Pinkham et al. (2011) and Najafabadi et al. (2018) there are provided descriptions in which parents assessed participants with structured scales and subscales. The findings showed that on the programme satisfaction questionnaire, parents reported high levels of satisfaction with the programme activities. Overall, parents reported that their children enjoyed the programme and also the programme provided an opportunity for exercise. Finally, only in one study (Yanardag, 2015) a structured instruction method (Most Least Prompting - MLP) was used to teach skills and evaluate the effectiveness of aquatic activities to participants with ASD. The results of the study showed that MLP was effective in teaching advance movement exploration skills in the water to participants with ASD.

\subsection{Outcomes of reviewed studies}

All the reviewed studies reported improvements in social behavior of participants with ASD (e.g., reduced anxiety, increased social interactions and play). More specifically, SPARK program by the study of Najafabadi 
et al. (2018) showed that participants with ASD display a substantial improvement in social interaction. Aquatic activities promoted psychological and social development such as self-esteem, self-confidence, and selfcompetence which are crucial factors for socialization. Furthermore, it seems that aquatic activities are a fun alternative exercise which encourages positive response and provides opportunities for children and adolescents with ASD to develop social and communication skills with other individuals. Pan (2010) who investigated the effects of a ten-week aquatic exercise program on pool skills and social behaviors of sixteen children with ASD covered both social competencies, such as peer relations, self-compliance, and antisocial behaviors (e.g., antisocial-aggressive). Results showed that aquatic activities programs have a potential effect on the development of social skills for individuals with ASD. As for the study of Fragala-Pinkham et al. (2011), all participants liked the aquatic programme and reported improvements in swimming skills and playing water games. In addition, parents reported high levels of satisfaction with the aquatic activities and reported that their children enjoyed the programme. Oucker (2016) evaluated in her study the use of behavioral skills teaching in-water safety skills to children with ASD and showed that the participants improved in targeted individual components of potentially life-saving and social skills. On the other hand, Battaglia et al. (2019) found that swimming pool activities trained psychomotor skills and increased adaptive behaviors in children with ASD. Moreover, Primenta et al. (2016) found in their study that children with ASD demonstrated positive results for the evolution of aquatic skills, and better participation in the proposed activities. The results of the study by Yanardag et al. (2015) showed that MLP was effective in teaching advance movement exploration skills in the water to children with ASD. This enjoyable intervention and appealing setting increased the repertoire of leisure skills and level of physical activity.

\subsection{Research methodology}

Three studies collected data using an observation schedule (Battaglia et al., 2019; Primenta et al., 2016; Tucker, 2016) with a video recording of the sessions. Data were scored according to a scale which aimed to identify the number of components of each skill or behavior, the participants completed independently. Because groups were not randomly selected, Fragala - 
Pinkham et al. (2011) examined the extent of differences in key confounding variables between experimental and control groups. Responses to the openended questions on the parent satisfaction questionnaire were reviewed and key themes were identified. The same data analysis was used in the study by Najafabadi et al. (2018), by Yanardag et al. (2015) and by Pan (2010) (see Table no. 4).

Table no. 4. Description of studies

\begin{tabular}{|c|c|c|c|c|}
\hline Pan (2010) & $\begin{array}{l}8(\mathrm{~N}=8) \text { boys } \\
\text { with High- } \\
\text { Functioning } \\
\text { Autism } \\
\text { (HFA) } \\
8 \text { boys }(\mathrm{N}=8) \\
\text { with Asperger } \\
\text { syndrome } \\
\text { (n=8) } \\
6 \text { to } 9 \text { years } \\
\text { old }\end{array}$ & $\begin{array}{l}\text { 10-week WESP } \\
\text { intervention } \\
20 \text { sessions/90 } \\
\text { minutes per } \\
\text { session) (social } \\
\& \text { floor warm- } \\
\text { up activities, } \\
\text { one-to-two } \\
\text { small group } \\
\text { instruction, } \\
\text { whole group } \\
\text { activities cool- } \\
\text { down } \\
\text { activities). }\end{array}$ & $\begin{array}{l}\text { Group A had a } \\
\text { significantly lower } \\
\text { score on } \\
\text { hostile/irritable } \\
(\mathrm{t}=-6.99, d f .=7, \\
\mathrm{p}<0.01), \\
\text { antisocial/aggressive } \\
(\mathrm{t}=-4.40, d f .=7, \\
\mathrm{p}<0.01) \\
\text { Defiant/ disruptive } \\
(\mathrm{t}=-7.07, d f .=7, \\
\mathrm{p}<0.01) \text { and } \\
\text { antisocial behavior } \\
\text { total }(\mathrm{t}=7.88, d f .=7, \\
\mathrm{p}<0.01 \\
\\
\text { Group B displayed a } \\
\text { significant } \\
\text { difference on social } \\
\text { competence total } \\
(\mathrm{t}=6.24, d f .=7, \\
\mathrm{p}<0.01) \text { also had a } \\
\text { lower score on } \\
\text { hostile/irritable } \\
(\mathrm{t}=-4.71, d f .=7, \\
\mathrm{p}<0.01) \& \\
\text { antisocial } \\
\text { Behavior total } \\
(\mathrm{t}=-3.95, d f .=7, \\
\mathrm{p}<0.01)\end{array}$ & $\begin{array}{l}2 \text { groups of } \\
\text { children with } \\
\text { ASDs were } \\
\text { paired up } \\
\text { with the same } \\
\text { instructor for } \\
10 \text { week } \\
\text { WESP } \\
\text { intervention } \\
\text { (2 times per } \\
\text { week/90 min } \\
\text { per session) } \\
\text { SSBS-2 was } \\
\text { used to assess } \\
\text { both social } \\
\text { competence \& } \\
\text { antisocial } \\
\text { behavior } \\
\text { Percentage } \\
\text { scores in each } \\
\text { stage for aquatic } \\
\text { skills \& T- } \\
\text { scores for } \\
\text { social } \\
\text { behaviors } \\
\text { were } \\
\text { examined in } \\
\text { relation to } \\
\text { treatment } \\
\text { using a two- } \\
\text { way ANOVA } \\
\text { (group } \times \text { time) } \\
\text { with repeated } \\
\text { measures on } \\
\text { one factor. }\end{array}$ \\
\hline
\end{tabular}




\begin{tabular}{|c|c|c|c|c|}
\hline Citation & Participants & Procedure & Outcomes & $\begin{array}{c}\text { Research } \\
\text { Methodology }\end{array}$ \\
\hline $\begin{array}{l}\text { Najafabadi et } \\
\text { al. (2018) }\end{array}$ & $\begin{array}{l}28 \text { children } \\
\text { with ASD } \\
5-12 \text { years old }\end{array}$ & $\begin{array}{l}\text { SPARK } \\
\text { program: warm } \\
\text { up \& cool } \\
\text { down activities- } \\
36 \text { sessions ( } 40 \\
\text { min) }\end{array}$ & $\begin{array}{l}\text { ATEC questionnaire } \\
\text { Positive effect on } \\
\text { sociability (self- } \\
\text { esteem, confidence, } \\
\text { competence) } \\
(\mathrm{F}=7.86, \mathrm{p}=0.01) \\
\text { GARS-2 } \\
\text { questionnaire effect } \\
\text { on social interaction } \\
(\mathrm{F}=7.81, \mathrm{p}=0.01)\end{array}$ & $\begin{array}{l}\text { Pre/Posttest } \\
\text { design was } \\
\text { used. } \\
\text { Effect of } \\
\text { intervention } \\
\text { on } \\
\text { participants } \\
\text { performance } \\
\text { across two } \\
\text { groups (EG- } \\
\text { CG) } \\
\text { Repeated } \\
\text { measures } \\
\text { were used. } \\
\text { Post-hoc } \\
\text { analysis, } \\
\text { (p=0.05) }\end{array}$ \\
\hline $\begin{array}{l}\text { Battaglia et } \\
\text { al. (2019) }\end{array}$ & $\begin{array}{l}\text { Two boys } \\
(\mathrm{N}=2) \text { with } \\
\text { ASD } \\
\text { One girl } \\
(\mathrm{N}=1) \text { with } \\
\text { ASD } \\
11-15.11 \\
\text { years old }\end{array}$ & $\begin{array}{l}\text { CI-MAT } \\
\text { protocol: } \\
\text { Ludic water } \\
\text { activities } \\
\text { (dance bubbles } \\
\text { with water), } 12 \\
\text { weeks (45-50 } \\
\text { min) }\end{array}$ & $\begin{array}{l}\text { The higher } \\
\text { proportion of gains } \\
\text { was observed in the } \\
\text { sensitivity of other's } \\
\text { presence and eye } \\
\text { contact } \\
\text { Communication=2, } \\
10-3.7 y \\
\text { Daily Skills=2.8- } \\
2.10 y \\
\text { Socialization=2- } \\
2.6 y\end{array}$ & $\begin{array}{l}\text { VABS- } \\
\text { Vineland } \\
\text { Adaptive } \\
\text { Behavior } \\
\text { Scales to } \\
\text { measure } \\
\text { adaptive } \\
\text { behaviors for } \\
\text { independent } \\
\text { life } \\
\text { Children } \\
\text { were } \\
\text { videotaped (8 } \\
\text { behaviors) by } \\
\text { a trained } \\
\text { operator for } \\
50 \text { min \& } \\
\text { their coach in } \\
\text { the pool. }\end{array}$ \\
\hline
\end{tabular}




\begin{tabular}{|c|c|c|c|c|}
\hline Citation & Participants & Procedure & Outcomes & $\begin{array}{c}\text { Research } \\
\text { Methodology }\end{array}$ \\
\hline $\begin{array}{l}\text { Primenta et } \\
\text { al. (2016) }\end{array}$ & $\begin{array}{l}4 \text { boys }(\mathrm{N}=4) \\
\text { with Autism } \\
1 \text { girl }(\mathrm{N}=1) \\
\text { PPD with } \\
\text { traces of } \\
\text { Autism } \\
9-25 \text { years old }\end{array}$ & $\begin{array}{l}15 \text { classes, with } \\
\text { a duration of } 80 \\
\text { min. } \\
\text { Four moments } \\
\text { of different } \\
\text { activities } \\
\text { (floating, breath } \\
\text { control \& } \\
\text { propulsion, } \\
\text { swim strokes). }\end{array}$ & $\begin{array}{l}\text { Positive } \\
\text { developments in } \\
\text { three tasks of } \\
\text { inputs/outputs } \\
\text { (taking a shower, } \\
\text { getting in and out of } \\
\text { the pool by the } \\
\text { ladder). } \\
\text { Most of the students } \\
\text { only performed with } \\
\text { verbal \& gestural } \\
\text { instruction \& } \\
\text { without the teachers } \\
\text { physical conduct. }\end{array}$ & $\begin{array}{l}\text { Instructions } \\
\text { explained } \\
\text { verbally \& } \\
\text { directly } \\
\text { Explanation } \\
\text { was } \\
\text { performed } \\
\text { with images } \\
\text { by the } \\
\text { teachers who } \\
\text { helped } \\
\text { physically } \\
\text { (driving } \\
\text { physics) } \\
\text { A camera } \\
\text { was used for } \\
\text { recording } \\
\text { (e.g., what } \\
\text { happened at } \\
\text { the moment). }\end{array}$ \\
\hline $\begin{array}{l}\text { Tucker } \\
\text { (2016) }\end{array}$ & $\begin{array}{l}3 \text { boys }(\mathrm{N}=3) \\
\text { with Mild \& } \\
\text { High- } \\
\text { Functioning } \\
\text { Autism } \\
\text { (HFA) } \\
7-8 \text { years old }\end{array}$ & $\begin{array}{l}\text { Training for } \\
\text { push/turn/grab } \\
12 \text { weeks/3 } \\
\text { days per week } \\
\text { for } 15 \mathrm{~min}\end{array}$ & $\begin{array}{l}\text { One of three } \\
\text { participants was } \\
\text { able to master all } \\
\text { three skills } \\
\text { (Push/Turn/Grab } \\
\text { Skill). } \\
\text { The first participant } \\
\text { maintained all skills } \\
\text { at one week and 1- } \\
\text { month past mastery } \\
\text { date. } \\
2 \text { of three } \\
\text { participants } \\
\text { maintained two of } \\
\text { the three skills at the } \\
\text { one week and one- } \\
\text { month maintenance } \\
\text { dates. }\end{array}$ & $\begin{array}{l}\text { A multiple } \\
\text { baseline } \\
\text { across skills } \\
\text { design was } \\
\text { used to } \\
\text { determine the } \\
\text { effectiveness } \\
\text { of BST + IST } \\
\text { on the } \\
\text { acquisition of } \\
\text { three skills } \\
\text { for each of } \\
\text { the } \\
\text { participants. }\end{array}$ \\
\hline
\end{tabular}




\begin{tabular}{|c|c|c|c|c|}
\hline Citation & Participants & Procedure & Outcomes & $\begin{array}{c}\text { Research } \\
\text { Methodology }\end{array}$ \\
\hline $\begin{array}{l}\text { Fragala- } \\
\text { Pinkham et } \\
\text { al. }(2011)\end{array}$ & $\begin{array}{l}11 \text { boys } \\
(\mathrm{N}=11) \\
1 \text { girl }(\mathrm{N}=1) \\
\text { with Asperger } \\
\text { syndrome, } \\
\text { HFA or PDD- } \\
\text { NOS } \\
6.3-12.9 \text { years } \\
\text { old }\end{array}$ & $\begin{array}{l}\text { Aquatic } \\
\text { exercise } \\
\text { program two } \\
\text { times per week } \\
\text { for } 14 \text { weeks/40 } \\
\text { min per session } \\
\text { (20-30 min } \\
\text { aerobic } \\
\text { exercise, } 5-10 \\
\text { min muscular } \\
\text { strength } \\
5 \text { min cool } \\
\text { down/stretching } \\
\text { activities). }\end{array}$ & $\begin{array}{l}\text { Participants playing } \\
\text { water games \& also } \\
\text { liked being with the } \\
\text { other children and } \\
\text { instructors during } \\
\text { the class. } \\
\text { A significant } \\
\text { difference (p } 1 / 40.01 \text { ) } \\
\text { was found between } \\
\text { the amount of time } \\
\text { children were able } \\
\text { to exercise at the } \\
\text { beginning of the } \\
\text { programme and the } \\
\text { last } 4 \text { weeks. }\end{array}$ & $\begin{array}{l}\text { Satisfaction } \\
\text { was } \\
\text { measured } \\
\text { with a } \\
\text { Questionnaire } \\
\text { at the end of } \\
\text { the 14-week } \\
\text { programme } \\
\text { by children } \\
\text { and their } \\
\text { parents. } \\
\text { Response } \\
\text { percentages } \\
\text { were } \\
\text { calculated for } \\
\text { the } \\
\text { Close-ended } \\
\text { items \& were } \\
\text { reviewed, key } \\
\text { themes were } \\
\text { identified. }\end{array}$ \\
\hline $\begin{array}{l}\text { Yanardag et } \\
\text { al. (2015) }\end{array}$ & $\begin{array}{l}\text { Three boys } \\
(\mathrm{N}=3 \text { ) with } \\
\text { ASD } \\
6 \text { years old }\end{array}$ & $\begin{array}{l}\text { Aquatic play } \\
\text { skills \& } \\
\text { exercise } \\
\text { training/12 } \\
\text { weeks at three } \\
\text { sessions per } \\
\text { week, each } \\
\text { lasting } 1 \text { hour. }\end{array}$ & $\begin{array}{l}\text { MLP was effective } \\
\text { in teaching advance } \\
\text { movement } \\
\text { exploration skills } \\
\text { through aquatic } \\
\text { activities to children } \\
\text { with ASD. } \\
\text { Parents' opinions } \\
\text { were positive on the } \\
\text { learning skills in } \\
\text { terms of } \\
\text { functionality \& this } \\
\text { enjoyable } \\
\text { intervention } \\
\text { increased the } \\
\text { repertoire of leisure } \\
\text { skills and the level } \\
\text { of physical activity } \\
\text { for their children } \\
\text { with ASD. }\end{array}$ & $\begin{array}{l}\text { Three 6-year } \\
\text { old children } \\
\text { with ASD } \\
\text { participated } \\
\text { in } 3 \text { different } \\
\text { aquatic skills, } \\
\text { essential for } \\
\text { movement } \\
\text { exploration in } \\
\text { water and } \\
\text { swimming, in } \\
\text { a one-to-one } \\
\text { training } \\
\text { format at } \\
\text { three sessions } \\
\text { per week. } \\
\\
\text { A multiple } \\
\text { probe design } \\
\text { across } \\
\text { behaviors } \\
\text { was used to } \\
\text { analyze the } \\
\text { effects of } \\
\text { MLP. }\end{array}$ \\
\hline
\end{tabular}




\section{Discussion}

Summaries of these seven studies revealed that the existing literature can be described as limited with respect to the overall corpus of studies, and the relatively few numbers of participants with ASD $(\mathrm{N}=72)$. In terms of methodological quality, the most important limitation is that many of these studies provide the use of a strong experimental design and the positive findings across a wide range of dependent variables do suggest that increasing water exercise and/or activities of individuals with ASD is likely beneficial.

Results of Zanobini and Solari's (2019) study argue with the findings of this review. The two researchers suggested that perhaps aquatic activities are an advantage in relational skills. In addition, water exercise may produce positive changes both in behavior and physical fitness. According to Blankenship (2017), physical education in different environments, in this case, aquatic environment, focuses not just on physical benefits but also on the psychological principles and strategies which help children to develop prosocial behavior, and self-perception. One possible explanation for the improvements that involve increases in social behavior in both children and adolescents with ASD are the activities which provide a way to meet new people in a fun, no-pressure situation. In general, swimming pools serve as a hub for all sorts of activities, social gatherings, and community activities. For instance, study results of Pan (2010) and Najafabadi et al. (2018) argue that group aquatic activities create an adapted atmosphere in which a child or an adolescent with ASD interact with other people, even if he or she has never met before. From a social development standpoint, this aspect of group work in the water can be valuable as a child learns how to interact and be confident around different personalities. Similar results involving increased social behaviors were also found in Battaglia et al. (2019) and Primenta et al. (2016) studies. The active practice facilitated social changing perspective. Fragala-Pinkham et al. (2011) and Yanardag et al. (2015) argued that the opportunity of young children with ASD to dynamically engage with others in a skilled, supportive, and reciprocal manner is a key contributory element of aquatic programs. Based on the results of Tucker's (2016) study, individuals with ASD can learn social skills and attitudes during an aquatic play, as they learn how to be cooperative and be empathetic with others. 
Regarding the first aim of this paper, there is a general consensus across the studies of this review that aquatic activities have developed social skills among children and adolescents with ASD, at least as measured by tests and observations. It appears that aquatic playing activities have a more pronounced effect than other swimming exercises. Aquatic playing activities were compared in four studies involving a total of 60 participants and, in all cases, aqua activities produced more substantial improvements (Battaglia et al., 2019; Fragala-Pinkham, 2011; Pan, 2010; Primenta et al., 2016). Observations of positive effects following aquatic activities were assessed in three studies involving a total of twenty-two participants (Battaglia et al., 2019; Pan, 2010; Tucker, 2016). This suggests that in some cases multiple sessions per day may be preferable (Battaglia et al., 2019). Similar results across other studies indicate the need for more longitudinal studies. Regarding the second aim, the most interesting result is that all of the studies agree that aquatic activities can be applied better by physical educators and instructors who have training in these techniques because these activities need more adaptations for participants with ASD. The primary goal of physical educators is the combination of exercise or play and cooperation among participants with ASD. Finally, referring to the third aim, aquatic activities/programmes researchers worked to establish lines of research.

\subsection{Limitations and Recommendations}

The effect of aquatic activities on social skills and specifically on communication, friendship and cooperation are totally conclusive, thus it can be suggested that it enhances the theoretical framework which supports the practice by offering opportunities to individuals with ASD to enhance their social skills through social interactions with others. In this review, the researcher chose to present articles which have as participants only children and adolescents with ASD. Research in future studies can present and analyze numerous strategies of aquatic and swim activities and demonstrate to physical educators how to reinforce the social skills of individuals with ASD and other disabilities. 


\section{References}

- Aleksandrović, M., Jorgic, B., Block, M., \& Jovanovic, L. (2015). The effects of aquatic activities on physical fitness and aquatic skills in children with autism spectrum disorders: a systematic review. Series Physical Education \& Sport, 13(3), 351-362.

- American Psychiatric Association. (2013). DSM-V Diagnostic and Statistical Manual of Mental Disorders. 5th Edition. Washington, DC: American Psychiatric Association.

- Andrés-Roqueta, C., Adrian, J.E., Clemente, R.A., \& Villanueva L. (2016). Social cognition makes an independent contribution to peer relations in children with Specific Language Impairment. Research in Developmental Disabilities, 49, 277-290. https://doi.org/10.1016/j.ridd.2015.12.015

- Baron-Cohen S, Leslie, A.M, \& Frith, U. (1985). Does the autistic child have a theory of mind? Cognition, 21, 37-46. https://doi.org/10.1016/00100277(85)90022-8

- Battaglia, G., Agrò, G., Cataldo, P., Palma, A., \& Alesi, M. (2019). Influence of a specific aquatic program on social and gross motor skills in adolescents with autism spectrum disorders: Three case reports. Journal of functional Morphology and Kinesiology, 4(2), 27. https://doi.org/10.3390/jfmk4020027

- Blankenship, B. (2017). The psychology of teaching physical education from theory to practice. New York, NY: Roudletge.

- Bourdieu, P. (1990). The logic of practice. Stanford: Stanford University Press.

- Buchanan, A., Miedema, B., \& Frey, C.G. (2017). Parents' perspectives of physical activity in their adult children with autism spectrum disorder: A socialecological approach. Adapted Physical Activity Quarterly, 34(4), 401-420.

- Fragala-Pinkham, M.A., Haley, S.M., \& O’Neil, M.E. (2011). Group swimming and aquatic exercise programme for children with autism spectrum disorders: a pilot study. Developmental Neurorehabilitation, 14(4), 230-241. https://doi.org/ 10.3109/17518423.2011.575438

- Horvat, M., Croce, V.R., Pesce, C., \& Fallaize, E.A. (2019). Developmental and adapted physical education: Making ability count. New York: Routledge.

- Kanupka, J.W., Oriel, K.N., George, C.L., Hanna, A., Lloyd, S., \& Snyders, O. (2016). The impact of participation in an aquatic exercise program on behavior in children with autism spectrum disorder: A preliminary study. Austin Journal Autism \& Related Disabilities, 2(2), 1-6.

- Kraft, E., \& Leblanc, R. (2018). Instructing children with autism spectrum disorder: Examining swim instructors' knowledge building experiences. Disability and Health Journal, 11(3), 451-455. https://doi.org/10.1016/ j.dhjo.2017.11.002 
- Lee, J., \& Porretta, D. (2013). Enhancing the motor skills of children with autism spectrum disorders: a pool-based approach. Journal of Physical Education, Recreation \& Dance, 84(1), 41-45. https://doi.org/10.1080/ 07303084.2013.746154

- Lepore, M., Columna, L., \& Litzner, F.L. (2015). Assessments and activities for teaching swimming. Champaign, IL: Human Kinetics.

- Lepore, M., Gayle, G., \& Stevens, S. (1998). Adapted aquatics programming: A professional guide. Champaign, IL: Human Kinetics.

- Najafabadi, G.M., Sheikh, M., Hemayattalab, R., Hossein Memari, A., Aderyani, R.M., \& Hafizi, S. (2018). The effect of SPARK on social and motor skills of children with autism. Pediatrics \& Neonatology, 59(5), 481-487.

- Pan, Y. C (2010). Effects of water exercise swimming program on aquatic skills and social behaviors in children with autism spectrum disorders. Autism, 14(1), 9-28. https://doi.org/10.1177/1362361309339496

- Premack, D., \& Woodruff, G. (1978). Does the chimpanzee have a theory of mind? Behavioral Brain Science, 4, 515-526. https://doi.org/10.107/ S0140525X00076512

- Pimenta, R.A., Zuchetto, A.T., Bastos, T., \& Corredeira, R. (2016). Effects of a swimming program for young people with autism spectrum disorder. Revista Internacional de Medicina y Ciencias de la Actividad Física y el Deporte, 16(64), 789-806.

- Sato, T., Hodge, R.S., Casebolt, K., \& Samalot-Rivera, A. (2015). Physical education teacher candidates' beliefs about instructing students with disabilities in adapted aquatics. International Journal of Aquatic Research and Education, 9(3), 308-328. https://doi.org/10.25035/ijare.09.03.07

- Templier, M., \& Paré, G. (2015). Transparency in literature reviews: an assessment of reporting practices across review types and genres in top IS journals. European Journal of Information Systems, 24, 1-48. https://doi.org/10.1080/ 0960085X.2017.1398880

- Tucker, M. (2016). Teaching water safety skills to children with autism using behavioral skills training. Master Thesis, University of North Texas.

- Winnick, P.J., \& Porretta, L.D. (2016). Adapted physical education and sport. Champaign, IL: Human Kinetics.

- Winnick, J.P. (2004). Educação Física e Esportes Adaptados. São Paulo: Manole.

- Yanardag, M., Erkan, M., Yýlmaz, I., Arýcan, E., \& Duzkantar, A. (2015). Teaching advance movement exploration skills in water to children with autism spectrum disorders. Research in Autism Spectrum Disorders, 9, 121-129.

- Zanobini, M., \& Solari, S. (2019). Effectiveness of the Program Acqua Mediatrice di Comunicazione (Water as a Mediator of Communication) on Social Skills, 


\section{Autistic Behaviors and Aquatic Skills in ASD Children. Journal Autism Developmental Disorders, 1-13.}

\begin{tabular}{|c|c|}
\hline $\begin{array}{l}\text { The online version of this article can be found at: } \\
\text { http://revped.ise.ro/category/2019-en/ }\end{array}$ & $\begin{array}{l}\text { Versiunea online a acestui articol poate fi găsită la: } \\
\text { http://revped.ise.ro/category/2019-ro/ }\end{array}$ \\
\hline$(C C)) B Y-N C-B A$ & $(c c))$ EY-NC-SA \\
\hline $\begin{array}{c}\text { This work is licensed under the Creative Commons } \\
\text { Attribution-NonCommercial-ShareAlike } 4.0 \\
\text { International License. }\end{array}$ & $\begin{array}{c}\text { Această lucrare este licen iată sub Creative } \\
\text { Commons Attribution-NonCommercial-ShareAlike } \\
4.0 \text { International License. }\end{array}$ \\
\hline $\begin{array}{c}\text { To view a copy of this license, visit } \\
\text { http://creativecommons.org/licenses/by-nc-sa/4.0/ } \\
\text { or send a letter to Creative Commons, } \\
\text { PO Box 1866, Mountain View, CA 94042, USA. }\end{array}$ & $\begin{array}{l}\text { Pentru a vedea o copie a acestei licen e, vizita } i \\
\text { http://creativecommons.org/licenses/by-nc-sa/4.0/ } \\
\text { sau trimite i o scrisoare către Creative Commons, } \\
\text { PO Box } 1866, \text { Mountain View, CA 94042, SUA. }\end{array}$ \\
\hline
\end{tabular}

